Journal of Social Sciences 8 (1): 50-53, 2012

ISSN 1549-3652

(C) 2012 Science Publications

\title{
Pra Na Wa Ka: The Development of Training Course for Continuing Buddhism
}

\author{
Phra Maha Pathawisak Romphothanthong, \\ Wisanee Siltragool and Anchalee Chantapo \\ The Research Institute of Northeastern Art and Culture, \\ Mahasarakham University, Tarad, Muang, \\ Mahasarakham, 44000, Thailand
}

\begin{abstract}
Problem statement: Buddhism is a religion that requires meditation, practice, intellectual precepts of the threefold-training such as morality, concentration and wisdom. The purpose of practicing Buddhism is the goal of deliverance through attaining knowledge and wisdom. The Pra Na $\mathrm{Wa} \mathrm{Ka}$ are newly ordained monks and needed to study both of the scriptures and the practice for appreciating understanding in morality, concentration and wisdom. A training model and guidelines are needed to improve the quality and efficiency of Pra $\mathrm{Na} \mathrm{Wa} \mathrm{Ka}$ because currently most of the monks who are the teachers lacked knowledge and are not ready to act as the Pra $\mathrm{Na} \mathrm{Wa} \mathrm{Ka} \mathrm{teacher,}$ because lack of the teaching media, lack of the proper knowledge of the teacher vocational, the lesson plan arrangement, the psychology of teaching, lack of technique variety of teaching methods. Most of the temple had no education administration of the Pra $\mathrm{Na} \mathrm{Wa} \mathrm{Ka}$ who ordained in short-term, within 3 days 7 days 15 days or to one month, lack of the short period course to study about Buddhism, the Pra $\mathrm{Na} \mathrm{Wa}$ Ka cannot accurately recite the Pali words, the Pra $\mathrm{Na} \mathrm{Wa} \mathrm{Ka}$ who were ordained were not motivated and faithful in learning and low morality. Approach: This research intended to study the history of the education administration of the Pra $\mathrm{Na} \mathrm{Wa} \mathrm{Ka} \mathrm{(Newly} \mathrm{ordained} \mathrm{monk)} \mathrm{and} \mathrm{to} \mathrm{study}$ about the problems and need of the Pra $\mathrm{Na} \mathrm{Wa} \mathrm{Ka}$ in knowledge about Buddhism and to develop the curriculum and the training package of the Pra $\mathrm{Na}$ Wa Ka in Buddhism. Results: The Pra $\mathrm{Na} \mathrm{Wa} \mathrm{Ka}$ traing course is a curriculum to study Buddhism through 3 training courses; (1) Basic Course: 3 days for initiation 7 days, (2) Intermediate course 7 days for initiation 15 days and (3) Long period course 15 days for initiation more than 30 days. The training courses were accompanied by a training kit to understand the main precepts of morality, concentration and wisdom. The curriculum was successful in providing Pra $\mathrm{Na} \mathrm{Wa} \mathrm{Ka}$ with knowledge and learning tools in order to understand the teachings from senior monks and Buddhist teachers. Conclusion: The effectiveness of the developed training course and success of the examination results of the Pra $\mathrm{Na} \mathrm{Wa} \mathrm{Ka}$ will ensure that Buddhism will continue to be propagated to society in its purest form and will benefit the community and society as a whole, bringing peace and prosperity.
\end{abstract}

Key words: Pra Na Wa Ka, newly ordained monk, buddhism

\section{INTRODUCTION}

Buddhism is a religion that requires meditation, practice, intellectual precepts of the threefold- training such as morality, concentration and wisdom. Studying the Buddhism philosophy was traditionally and relied on oral tradition such as the Vedas in historic India were passed down via oral tradition through the memory of Brahmans (Tularam, 2010). The purpose of practicing Buddhism is the goal of deliverance through attaining knowledge and wisdom. The Pra $\mathrm{Na} \mathrm{Wa} \mathrm{Ka}$ are newly ordained monks and needed to study both of the scriptures and the practice for appreciating understanding in morality, concentration and wisdom. This research intended to study the history of the education administration of the Pra Na Wa Ka (Newly ordained monk) and to study about the problems and need of the Pra Na Wa Ka in knowledge about Buddhism and to develop the curriculum and the training package of the Pra Na Wa Ka in learning Buddhism.

\section{MATERIALS AND METHODS}

The research use qualitative research methodology and were select the collecting groups, as 15 persons from the senior member of the Monk Order, 25 persons

Corresponding Author: Phra Maha Pathawisak Romphothanthong, The Research Institute of Northeastern Art and Culture, Mahasarakham University, Tarad, Muang, Mahasarakham, 44000, Thailand 
from the Pra $\mathrm{Na} \mathrm{Wa} \mathrm{Ka}$ and 60 individuals from the relevant sampling groups. The collecting instruments used to collect data include the observation form, interviewing form and data collection from document analysis, related research studies and research documents, field data, group discussions and workshop conferences. The research data was analyzed by triangulation techniques and presented the research results by descriptive analysis.

The research and sampling group was conducted in Bangkok due to the density of the population and diversity of the sampling group. The research focused on the research study and application of the training courses at 5 temples in Bangkok. These temples are; Wat Bowonniwet Wihan Ratchaworawihan temple, Wat Sa Ket Ratchaworamahawihan temple, Wat Rat O Rasa Ram temple, Wat Rakhang Kho Si Ta Ram Woramahawihan temple and Wat Yai Rom Pen Phuenthi Sueksa temple. These temples were selected because of the large numbers of newly ordained monks every year. The research period was from May 1st 2010 to January 1st 2011.

\section{RESULTS}

Background: Khao Phansa festival (marking the beginning of Phansa, also known as the "Buddhist Lent" period) is a period of 3 lunar months during the rainy season when Buddhist monks retreat to their temples for Dharma study and avoid any unnecessary travel. Although they may still go out to seek alms during the day, they must return to sleep in their temple and aren't permitted to defrock during Phansa.The tradition comes from early Buddhism in India, where holy men and sages would minimize travel during the rainy season to avoid accidentally killing young animals, insects or plants. Ordinary Buddhists also do their part by pledging to give up various vices during the Phansa period, in much the same way as Christians during Lent. Being a monk during Phansa is thought to bring great merit and is an act that brings pride not only to the man himself but to his entire family. Many Thai males will ordain as monks for Phansa before getting married, although some opt to ordain for shorter periods instead. The Phansa period is marked with 2 large nationwide festivals-Khao Phansa festivals which marks the start of Phansa and commonly falls in July and the end of Buddhist Lent which is usually in October. Monks use the retreat to meditate more intensively. Lay people will often use this period to adopt more ascetic practices, abstaining from meat, alcohol or cigarettes, for example. Wan Khao Pansa is often referred to as Buddhist Lent, as its emphases on reflection and self-denial bear outward resemblance to the Christian Lenten period (though pre-dating it by over 500 years). It is also a time when many young Thai men ordain and join the monkhood for part or all of the period of the rains retreat. This is a traditional rite of passage for most young Thai men and it creates valuable merit for the whole family.

The history of education administration of the Pra $\mathrm{Na} \mathrm{Wa} \mathrm{Ka}$ (Newly ordained monk) refers to Phra Mahasamanajao Krom Phraya Wachirayanwaroros of the Bovornnivesviharn Rajaworaviharn Temple, Bangkok, was the originator of the new and reformed education of the Monk Community in the year 2435 B.E. The education and examination level was called Nak Thamm which was designed for the ordained Sangha i.e. Buddhist monks, novices and nuns) while the Thammaseuksa was designed for lay Buddhists. Currently both types of education practices are also referred as the levels of examination for Buddhist Monks and Nak Thamm curriculum had three levels, the third class the second class and the first class of the Nak Thamm. These levels were the classical basic education of the Monk Community, which is practiced in every temple by applying the Nak Thamm curriculum to train the Pra $\mathrm{Na} \mathrm{Wa} \mathrm{Ka}$ in the 3 months of the rainy retreated period, but the Pra $\mathrm{Na} \mathrm{Wa} \mathrm{Ka}$ who came in with the short-term ordaining out of the rainy-restrict period did not study with the Nak Thamm curriculum, if any, the study was organized by using the divine books the third class Nak Thamm and had the elder monk to introduced to the basics of the 10 routine practice of the monk, that had 10 activities, such as, the morning recitation, the evening recitation, meditation practice exercised and had the teachers to counseling about the dharma doctrine and the basic religious ceremony (Wijit, 2000). The Pra $\mathrm{Na} \mathrm{Wa} \mathrm{Ka}$ who were ordained since November 2010 to January 2011 in 5 temples of the research area, had the total number of 166 persons on average 25-35 years of age, a bachelor's degree and the initiation period about 7-15 days.

Current problem and issues: Most of the monks who are the teachers lacked knowledge and are not ready to act as the Pra $\mathrm{Na} \mathrm{Wa} \mathrm{Ka}$ teacher, because lack of the teaching media, lack of the proper knowledge of the teacher vocational, the lesson plan arrangement, the psychology of teaching, lack of technique variety of teaching methods. Most of the temple had no education administration of the Pra $\mathrm{Na} \mathrm{Wa} \mathrm{Ka}$ who ordained in short-term, within 3 days 7 days 15 days or to one month, lack of the short period course to study about Buddhism, the Pra $\mathrm{Na} \mathrm{Wa} \mathrm{Ka}$ cannot accurately recite the Pali words, the Pra $\mathrm{Na} \mathrm{Wa} \mathrm{Ka}$ who were ordained were not motivated and faithful in learning and low morality. 


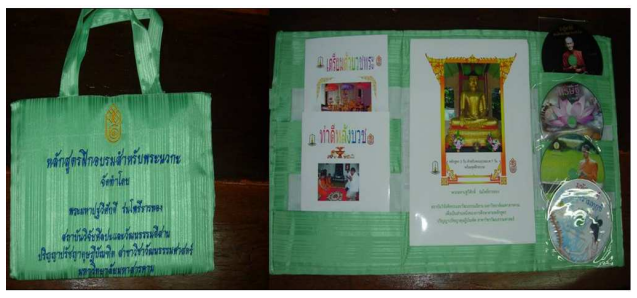

Fig. 1: Pra Na Wa Ka education kit

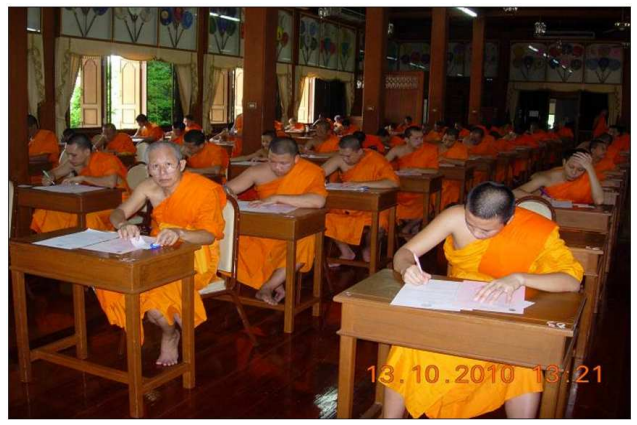

Fig. 2: Examination

The lack of interest and dedication in learning Buddhism is consistent with Kaeolan et al. (2011) in which the three major obstacles in listening to Buddhist principles or Dharma include lack of trust in the preachers, the content and ineffective presentation methods. The needs of the Pra $\mathrm{Na} \mathrm{Wa} \mathrm{Ka}$ about Buddhism include 6 topics, such as (1) Principle of the monks' actions, (2) Basic Vinaiya (discipline), (3) Basic of the Buddha history, (4) Dharma Scripture, (5) Basic religious ceremonies (6) Religious ceremonies practices.

Training and curriculum development: The curriculum development and training package of the Pra Na Wa Ka in learning Buddhism, the course of curriculum development would be three courses, there were 1 Basic Course: 3 days for initiation 7 days, 2 Intermediate course 7 days for initiation 15 days and 3 Long period course 15 days for initiation more than 30 days, each course the contents and time were different and each course consists with the training package, the details of training, course topics and contents for training, purposes, time table assessment, teaching media, course evaluation and measurement and testing. The entire training course content, guidelines and study materials and mediums are integrated into a Pra $\mathrm{Na} \mathrm{Wa}$ Ka Education Kit as seen in Fig. 1, in which was utilized by the Pra Na Wa Ka in the preparation for the final exam in Fig. 2.

\section{DISCUSSION}

The examination and evaluation Pre-test and Posttest are consistent with Tyler (1950) who's theory proposed the educational goals of curriculum management that educational institutions should focus, the required learning experiences that will fulfill goals and targets, how to organize those experiences for efficiency, how to assess the learning experiences to see if the set targets and goals were achieved and measuring the satisfaction level of participants. Cooperation by observing the moral behaviors of the monks is consistent with Behaviorist Theory of Sirisukphaibun (1985) and Durkheim (1982) in human behavior and conclusion that the factors that affect human behavior comes from the surrounding condition of each individual which means that if teachers can organize the appropriate learning environment, it will enable students to learn with more efficiency.

The Pra Na Wa Ka who had applied the kit and development model would acquire the knowledge and education of the scriptures within prescribed curriculum. At the end of the course the Pra $\mathrm{Na} \mathrm{Wa} \mathrm{Ka}$ would have the knowledge and understanding in Buddhism, the knowledge gained can be given to continue to point solutions to the social, introduce to how to have the effectively acting and the religion will be prosper as they had been studied. This is consistent with Phra Maha Sanya 2000 where the model and guideline to disseminate Buddhism found that the most effective method is the direct model. The direct model is the process of directly explaining the meaning of Buddhist principles and scriptures, present comparisons between Jataka stories and relative experiences. Or explain experiences that have moral teachings.

\section{CONCLUSION}

The Pra Na Wa Ka traing course is a curriculum to study the principles of Buddhism through 3 training courses and utilize the training kit to understand the main precepts of morality, concentration and wisdom. The curriculum was successful in providing Pra $\mathrm{Na} \mathrm{Wa}$ $\mathrm{Ka}$ with knowledge and learning tools in order to understand the teachings from senior monks and Buddhist teachers. The effectiveness of the developed training course and success of the examination results of the Pra $\mathrm{Na} \mathrm{Wa}$ Ka will ensure that Buddhism will continue to be propagated to society in its purest form and will benefit the community and society as a whole, bringing peace and prosperity.

\section{Suggestions and recommendations:}

Suggestions for application: The curriculum and learning kit for Pra $\mathrm{Na} \mathrm{Wa} \mathrm{Ka}$ is consistent with the current problems and conditions of teaching Buddhism in Thailand. The curriculum was developed to meet the 
needs and demand of related individuals who want to extend their knowledge and understanding of Buddhism and educational reform. The developed curriculum is an alternate choice in enhancing the development of administrators in Buddhism so that knowledge, understanding and skills can be applied practically, appropriately and conforms to the current problems and needs of every educational zone and area. The curriculum can also benefit Buddhist teachers and senior monks.

It is important to study the curriculum thoroughly before applying the various details. A complete understanding of the curriculum will ensure that the results are within the target outlined by the curriculum.

The important principle in applying the curriculum is planning and preparation. Related individuals and groups should study, analyze and understand the curriculum together before applying the program. It is important that all the individuals responsible for the administration of the curriculum have a common understanding in all aspects of the curriculum such as, budget, learning materials, learning documents and studies, locations and classrooms. All these details must be prepared and planned for so that they are readily available to support the learning activities.

A unit or organization should be created by the recruit of expert Buddhist teachers to support and develop other Buddhist teachers. The group's main duties would be to give lectures and follow up on the application of the developed curriculum and work closely with other Buddhist teachers.

Related parties and agencies must follow up on their development programs and make evaluations and assessments on a regular basis so that the results and conclusions can be analyzed and applied for future development and provide information for the planning of future development to be more efficient.

The Ministry of Culture and the Office of National Buddhism can apply the research results in the learning activities of temples by applying the short term curriculum for Pra $\mathrm{Na} \mathrm{Wa} \mathrm{Ka}$ as a guideline brining value to daily teachings.

Research recommendations: The Office of National Buddhism should support the production of learning kits and develop e-learning courses and curriculum that integrates multimedia. The office should also include a policy to support funding for temples so that the Buddhist teachers can receive extended training to enhance their knowledge and skills in teaching on a consistent basis so that they can apply their gained knowledge and experiences and adapt to modern conditions.
There should be an evaluation of Buddhist curriculum every 5 years which is in accordance with the National Higher Education act of 2005, so that the evaluations can be applied in improving the Buddhist curriculum.

The curriculum and training kit of Pra $\mathrm{Na} \mathrm{Wa} \mathrm{Ka}$ in regards to learning Buddhism should include the Buddhism discipline of Trai Khrong in which the monks must keep the learning kit with them as a requisite at all times just the same as they do with all three of their robes.

\section{REFERENCES}

Durkheim, E., 1982. The Rules of Sociological Method: and Selected Texts on Sociology and its Method. 1st Edn., Macmillan Press, Hong Kong, pp: 264.

Kaeolan, P.K.W.P., B. Yodmalee and S. Phothisane, 2011. Buddhist monk preachers: A study of preaching arts for increasing faith in Buddhism of Isan people. J. Soc. Sci., 7: 271-273. DOI: 10.3844/jssp.2011.271.273

Sirisukphaibun, S., 1985. Theory of learning. King Mongkut's University Of Technology North, Bangkok.

Tularam, G.A., 2010. Vedas and the development of arithmetic and algebra. J. Math. Stat., 6: 468480. DOI: $10.3844 / j m s s p .2010 .468 .480$

Tyler, R.W., 1950. Basic Principles of Curriculum and Instruction. 52nd Edn., University of Chicago Press, Chicago, ISBN: 0226820319, pp: 128.

Wijit, P.M.S.P., 2000. Education model and guideline in propagating buddhism of phrakhru phisan thama koson, dissertation. Mahachulalongkornrajavidyalaya University, Bangkok. 